\title{
Ocular System Dosage Form
}

National Cancer Institute

\section{Source}

National Cancer Institute. Ocular System Dosage Form. NCI Thesaurus. Code C69031.

A system that is placed in the eye, usually under the lower eyelid, from which the active and/or inert ing redient(s) diffuses through a membrane at a controlled rate. 